\title{
EXAMINING THE EFFECT OF BUSINESS ENVIRONMENT ON COMPETITIVE PRIORITY CHOICE: A STUDY OF MANUFACTURING FIRMS IN INDONESIA
}

\author{
Lina Anatan \\ Faculty of Economics, Maranatha Christian University Bandung
}

\begin{abstract}
Abstrak
Peningkatan kompetisi global, perubahan pasar dan teknologi yang cepat, peningkatan kompleksitas dan ketidakpastian menciptakan lingkungan persaingan baru. Perubahan-perubahan tersebut menyebabkan perusahaan manufaktur secara hati-hati melakukan perubahan dari sistem industri yang berbasis efisiensi menjadi sistem industri baru yang keberhasilannya tergantung pada tanggapan yang cepat terhadap permintaan konsumen akan produk yang berkualitas dan sesuai dengan kebutuhan. Untuk menanggapi kondisi tersebut dan untuk mencapai keunggulan kompetitif yang berkelanjutan dalam situasi persaingan bisnis saât ini, perusahaan manufaktur harus mengadopsi dan mengimplementasikan strategi manufaktur jika ingin tetap kompetitif. Dalam proses menyusun strategi manufaktur, pertimbangan lingkungan berperan signifikan dalam menentukan strategi manufaktur.

Penelitian ini dilakukan untuk menginvestigasi dampak dari lingkungan bisnis pada pemilihan strategimanufaktur. Perusahaan-perusahaan yang terdaftardiBiro Pusat Statistik (BPS) digunakan sebagai kerangka penentuan sampel dalam studi ini. Data dikumpulkan melaluii kuesioner yang dikirim melalui pos (ada 525 kuesioner) dan survei secara langsung ke 25 perusahaan. Total kuesioner dikirim ke 550 pimpinan (CEO) perusahaan manufaktur di Indonesia. Sebanyak 106 kuesioner dikirim kembali dan memberikan tingkat respon sebesar 19,27\%. Studi menghasilkan temuan ada hubungan antara faktor lingkungan seperti biaya bisnis, ketersediaan tenaga kerja, persaingan tidak sehat, dan dinamisasi pasar dengan pemilihan strategi manufaktur yang mempertimbangan prioritas kompetisi. Strategi yang paling banyak diadopsi oleh perusahaan manufaktur Indonesia berdasarkan urutan dari yang tertinggi ke terendah adalah strategi biaya, strategi kualitas, strategi fleksibel, dan strategi pengiriman. Hubungan yang signifikan antara lingkungan bisnis dan strategi manufaktur mengimplementasikan fakta bahwa lingkungan bisnis dipertimbangan sebagai variabel dasar (precursor) yang berhubungan sebab akibat dengan pemilihan strategi manufaktur yang mempertimbangkan prioritas kompetisi.
\end{abstract}

Kata kunci: environmental uncertainty, precursor variable, manufacturing strategy, sustainable competitive advantage.

\section{Introduction}

Today's markets are highly dynamic and customers demand ever higher performance from the manufacturers. These change are causing manufacturing firm to carefully examine a shift from industrial system driven by efficiency to post industrial system where success depend on quick response to customer demand for customized and high quality product. In the post-industrial environment, high quality and reliability, timely delivery, enhance customer service, rapid new product introduction, flexible system, and efficient capital deployment, are primary source of competition. 
In order to response this condition, manufacturing organizations must adopt and implement manufacturing strategy if they want to stay competitive. Manufacturing strategy is generally defined as the development of specific competitive strength based on the operation function and the use of manufacturing capabilities to achieve manufacturing goals (Amoako, 2003). In this manufacturing strategy formulation process, environmental considerations appear to play significant role in the determination of manufacturing strategy. Consideration of environment task, those forces which are out of the short run control of management, has been linked in operation management research, as precursor variable that causally related to strategic choice. Firms that fail to monitor their environment will have problems in successfully competing in the current competitive business environment. By ignoring the changes in the environment, a firm's strategy, structure and system become ineffective and dysfunctional. In the current of global competition, where a continuous turbulent and chaotic environment becomes the norm, the development and successful implementation of winning strategies is vital.

This research was conducted to the relationship among environment uncertainty and manufacturing strategy choice. It is meant to fill the gap in the operation management area. It is intended to understand the manufacturing strategy practiced by manufacturing firms in Indonesia as well as investigated the relationship between strategy and environment. The research questions investigated in this study are:

Do the environmental factors of business cost, labor availability, competitive hostility, and dynamism in the market have significant impact on the degree of emphasis on manufacturing strategy choice of low cost, quality, flexibility, and delivery?

The organization of the paper follow as: Section 1 discusses the introduction, research question, and the research motivation. Section 2 discusses literature review of the selected variables consist of environmental dynamism and manufacturing strategy, Section 3 deal with research framework and hypothesis. Research methodology and empirical data discussed in Section 4 including sample selection, response bias test, and variable measurement. Section 5 includes the result of the study. Finally, Section 6 presents the discussion and conclusion.

\section{LITERATURE REVIEW}

\subsection{Business Environment}

Business environment is a very important variable to be considered in determining organizational strategy. As the business environment changes over time, organizations must cope with the changes in order to survive and stay competitive. The external environment of an organization is viewed as the source of events and changing trends, which create opportunities and threats to organization (Swamidass \& Newell, 1987), so that organizations need to scan the environment in order to stay competitive and this scanning process should be a continuous process for the survival of the organization (Kourteli, 2000).

Porter (1980) described environment as those institution or forces outside organization (such as supplier, customers, competitors, government regulatory agencies, and public pressure) which the organization has little control. Those forces can potentially affect the organizational performance, therefore it is imperative for business enterprises not only to identify and monitor these forces but they must also manage them and adapt themselves to the forces of the environment (Gluek, 1980). Drucker (1977) stressed that environment influences such as economic forces can sets limit to what management can do as well as creates opportunities for management's action. However, they do not by themselves determine what a business is or what it does.

Miller and Friesen (1983) presented three environmental dimensions of munificence, dynamism, and complexity. Environmental munificence is the extent to which an environment can support sustained growth (Mintzberg, 1979). Munificence is often measured on a reserve scale as environmental hostility. Hostility in the environment is also described by several regulatory and restriction shortages of labor and raw materials and unfavorable demographic trends. Three scale which conceptually related to environmental munificence are cost of doing business (business cost), labor availability, and competitive hostility.

Environmental dynamism describes the degree of market instability over time and turbulence caused by interconnectedness between organizations (Aldrich, 1979 in McArtur \& Nystrom, 1991). Dynamism in environment 
manifested by predictability and unpredictability of change in customer taste, production, or services technology and the modes of competition in the firm's principal industries. Hostility in the environment is related to the degree or keen of competition in price, product, technological, and distribution. Environmental complexity describes the degree of heterogeneity and the dispersion of an organization's activities (Aldrich, 1979 in Mc Arthur and Nystrom, 1991). Heterogeneity in the environment concerns the differences in environment tactics, customer taste, product time, channel of distribution, etc.

Many research results have provided evidence that suggest environment as major determinant of performance in large firms. Stanwick and Pleshko (1995), Porter (1985), Manu and Sriram (1996) found that environment has strong influence on performance. At the same time, Li and Simerly (1998), Venkrataman and Prescott (1990), found that organizational performance depend upon a contingent relationship between business strategy and environment. Swammidass and Newell (1987) establish the important of business environment as a significant causal element in manufacturing strategy and business performance relationship. When environment is included in manufacturing strategy research, it is considered as a precursor variable that causally related to strategic choices (Swammidass and Newell, 1987; Ward et al, 1995; Badri et al, 2000; Amoako and Boye, 2001; Amoako, 2003).

\subsection{Manufacturing Strategy Dimensions}

In today's business competition, business organizations need to analyze the customers, the suppliers, the facility locations and the competitors in global terms (Krajewsky and Ritzman, 2002). They proposed that manufacturing strategy must be adopted to improve manufacturing operations. Manufacturing strategy is viewed as the effective use of manufacturing strengths as a competitive weapon for the achievement of business and corporate goals (Swamidas \& Newell, 1987).

Amoako (2003) define manufacturing strategy as the way a firm plans to deploy its manufacturing resources and to use its manufacturing capability to achieve its goals. Heizer and Render (2004) suggest that a successful manufacturing strategy must be consistent with environmental demands, competitive demand company strategy, and product life cycle. Manufacturing strategy reflects the goals and strategies of business and enables the manufacturing functions to contribute to the long term competitiveness and performance of the business (Wheelwright and Hayes, 1985).

Acommon theme in manufacturing strategy research has been describing manufacturer's choice of emphasis among key capabilities (Ward et al., 1995). This study used competitive priorities to describe these capabilities (Burgess et al., 1998). Competitive priorities include cost, quality, delivery, and flexibility strategies. Cost strategy is the production and distribution of a product with minimum expenses and wasted resources (Stonebraker \& Leong (1990). Lowering price will increase product or service demand, on the other hand it also reduces profit margin if the product cannot be produced at a lower cost. In order to compete based on costs, operation managers need to offer products and services at lower cost per unit by addressing labor, materials, scrap, and other overhead costs.

Quality strategy defined as specification, or meeting requested and promised delivery schedule (Ward et al., 1995). Quality strategy focuses on manufacture products and services that conform to the specification and customer needs. Therefore, improved quality is commonly thought to reduce cost, as doing thing correctly the first time can eliminate waste. Quality improvement is one way for organization to enhance its competitiveness.

Flexibility strategy is the organization ability to respond the rapid changes of products, services, and processes. Manufacturing flexibility is generally defined as the ability of manufacturing organizations to deploy and redeploy its resources effectively in response to changing environment and internal conditions (Gerwin, 1993). Manufacturing flexibility plans should be capable of switching very quickly from one product to another or one part to another almost instantly.

Delivery strategy defined as the dependability in meeting requested and promised delivery schedule, or speed in responding customer order. While, Leong, et al. (1990) defined delivery strategy as dependability of delivery (by meeting delivery schedule or promises) and speed of delivery (react quickly to customer order). 
Delivery performance measures include emphasis on those activities which are intended to increase either delivery reliability or delivery speed, for example of on time deliveries, accuracy in inventory status, average delay, and delivery lead time.

A summary of study concerning the impact of business environment on manufacturing strategy choice are listed in Table 1

Table 1.

A Summary of Study Concerning the Impact of Business Environment

\begin{tabular}{|c|c|c|c|c|c|}
\hline Author & $\begin{array}{c}\text { Variable } \\
\text { Used }\end{array}$ & $\begin{array}{l}\text { Additional } \\
\text { Factors }\end{array}$ & $\begin{array}{c}\text { Location } \\
\text { and Sample }\end{array}$ & $\begin{array}{l}\text { Method of } \\
\text { Analysis }\end{array}$ & Result \\
\hline $\begin{array}{l}\text { Swamidass } \\
\text { and Newell } \\
(1987)\end{array}$ & $\begin{array}{l}\text { Business } \\
\text { environ- } \\
\text { ment and } \\
\text { manu- } \\
\text { facturing } \\
\text { flexibility }\end{array}$ & $\begin{array}{l}\text { The } \\
\text { managerial } \\
\text { process on } \\
\text { decision } \\
\text { making }\end{array}$ & $\begin{array}{l}\text { USA, } \\
35 \text { manufac- } \\
\text { turers }\end{array}$ & $\begin{array}{l}\text { Path Analy- } \\
\text { sis }\end{array}$ & $\begin{array}{l}\text { The study found that environ- } \\
\text { mental uncertainty influence } \\
\text { manufacturing strategy and the } \\
\text { role manufacturing manager in } \\
\text { strategic decision making }\end{array}$ \\
\hline $\begin{array}{l}\text { Ward et al. } \\
\text { (1995) }\end{array}$ & $\begin{array}{l}\text { Business } \\
\text { environ- } \\
\text { ment and } 4 \\
\text { competitive } \\
\text { priorities }\end{array}$ & $\begin{array}{l}\text { Perfor- } \\
\text { mance } \\
\text { measure- } \\
\text { ment }\end{array}$ & $\begin{array}{l}\text { Singapore, } \\
236 \text { respon- } \\
\text { dents }\end{array}$ & & $\begin{array}{l}\text { The study found strong relation- } \\
\text { ships between environmental } \\
\text { factors such as labor availability, } \\
\text { competitive hostility, and market } \\
\text { dynamism and the operations } \\
\text { strategy choices encompassed } \\
\text { by competitive priorities. This } \\
\text { research also demonstrates that } \\
\text { environmental variables can } \\
\text { provide effective controls for in- } \\
\text { dustry effect in multiple industry } \\
\text { empirical studies in opera-tions } \\
\text { strategy. }\end{array}$ \\
\hline $\begin{array}{l}\text { Badri et al. } \\
(2000)\end{array}$ & $\begin{array}{l}\text { Business } \\
\text { environ- } \\
\text { ment and } 4 \\
\text { competitive } \\
\text { priorities }\end{array}$ & $\begin{array}{l}\text { Govern- } \\
\text { ment role } \\
\text { and politi- } \\
\text { cal environ- } \\
\text { ment }\end{array}$ & $\begin{array}{l}\text { Uni Emirat } \\
\text { Arab, } 103 \\
\text { respondents }\end{array}$ & $\begin{array}{l}\text { Path Analy- } \\
\text { sis }\end{array}$ & $\begin{array}{l}\text { The study found strong relation- } \\
\text { ships between environmental } \\
\text { factors competitive priorities. } \\
\text { Firm with high performance } \\
\text { used environmental dynamism } \\
\text { as source of resource to control } \\
\text { organizational effectiveness }\end{array}$ \\
\hline $\begin{array}{l}\text { Amoako } \\
\text { and Gyam- } \\
\text { pah } \\
(2003)\end{array}$ & $\begin{array}{l}\text { Business } \\
\text { environ- } \\
\text { ment and } 4 \\
\text { competitive } \\
\text { prio-rities }\end{array}$ & $\begin{array}{l}\text { Firm size } \\
\text { and assets } \\
\text { as control } \\
\text { variable }\end{array}$ & Ghana & $\begin{array}{l}\text { Regression } \\
\text { analysis }\end{array}$ & $\begin{array}{l}\text { The study found relationships } \\
\text { between environmental factors } \\
\text { and competitive priorities. The } \\
\text { degree of relationship based } \\
\text { on the firm size and who is the } \\
\text { owner (domestic or foreign) }\end{array}$ \\
\hline
\end{tabular}




\subsection{Research Framework and Hypothesis}

In the line with previous studies, the theoretical framework developed in this study is based on conceptual model of manufacturing strategy. The conceptual model has addressed the alignment among business environment, manufacturing strategy (Swammidass and Newell, 1987; Ward et al, 1995; Badri et al, 2000, Amoako, 2003).

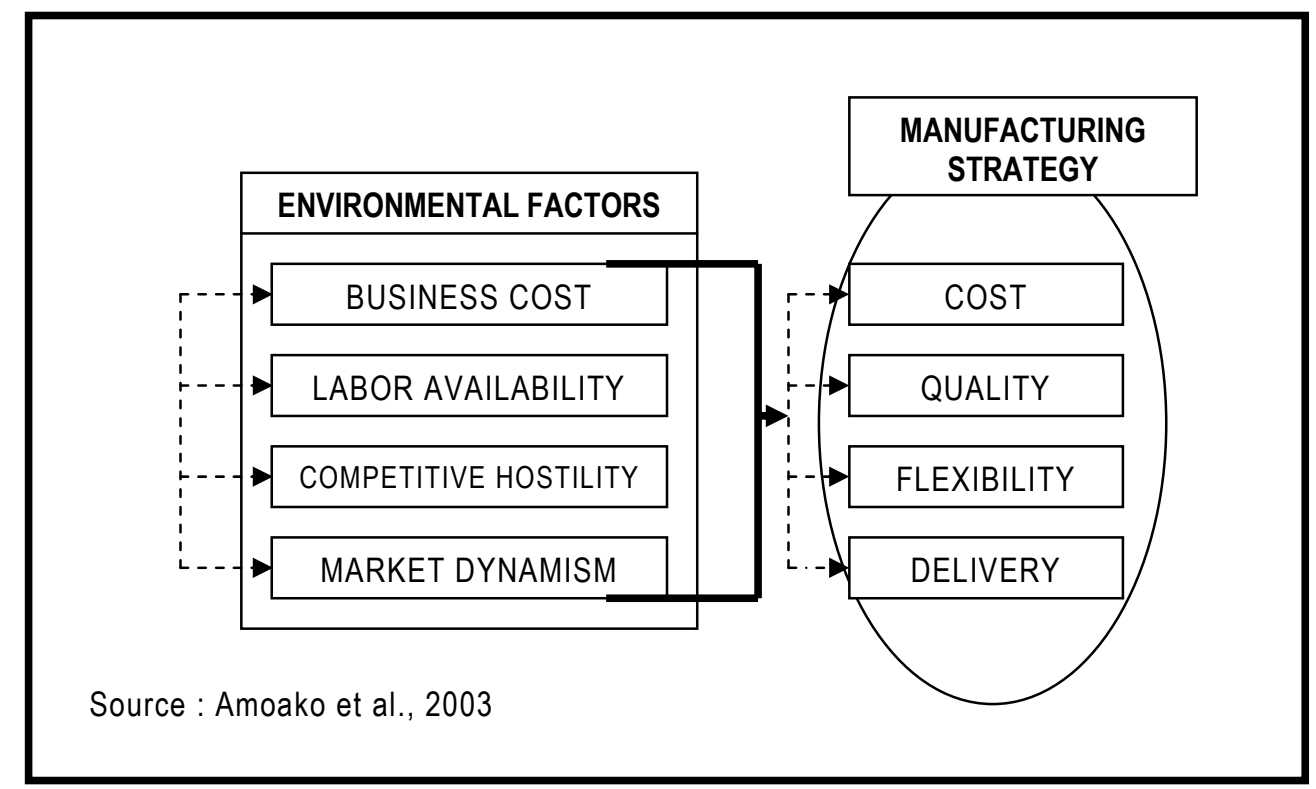

Figure 1.

Research Model

In order to test the proposed relationship between business environment and manufacturing strategy, this study developed the following hypothesis:

Hypothesis: The environmental factors of business cost, labor availability, competitive hostility, and dynamism have significant effect on the degree of emphasis on manufacturing strategy choice of low cost, quality, flexibility, and delivery.

\section{RESEARCH METHOD AND EMPIRICAL DATA}

\subsection{Sample Selection}

Companies listed in the statistic of center bureau were used as the sampling frame in this study. Populations of manufacture in Indonesia selected are those that are involved in manufacturing activities. Data was collected through mail questionnaires ( 525 questionnaires) and direct survey (25 questionnaires) addressed to the CEOs of large manufacturing companies in Indonesia. Size Classification of the firm was based on the number of employee: (1) firm with 5-19 employees were classified as small, (2) firm with 20-99 employees were classified as medium, (3) firm with more than 100 employees were classified as large. Classification used base on International Standard Industrial Classification (ISIC) which appropriate in Indonesian condition. Based on the criteria, sample was selected randomly from manufacturing firm with more than 100 employees. A total of 550 questionnaires sent out, 106 useable responses were received giving a return rate $19.27 \%$. Table 2 presents the questionnaires distributed to respondents. 
Table 2.

The Questionnaires Distribution

\begin{tabular}{lr}
\hline Questionnaires were sent & 550 \\
Returned but unusable & 21 \\
Returned and usable & 106 \\
Not returned & 423 \\
Rate of usable response & $106 / 550 \times 100 \%=19,27 \%$ \\
\hline
\end{tabular}

\subsection{Response Bias Test}

Data are collected through mailed survey and direct survey, there fore it is necessary to test the response bias, to investigate whether there is a different characteristic between the respondent answer collected from mailed survey and direct survey. The independent sample t test used to test the response bias. The results are shown in Table 3. Based on this result, we can conclude that characteristic between the respondent answer which collected from mailed survey and direct survey are not different. This conclusions are based on the significant value for each variables that more than 0.05 (sign > 0.05).

Table 3.

Response Bias Test

\begin{tabular}{cccccc}
\hline \multirow{2}{*}{ Variable } & \multicolumn{2}{c}{ Lavene's test } & \multicolumn{2}{c}{ t test } \\
& $\mathbf{F}$ & Sign & $\mathbf{t}$ & Sign & \\
\hline Business Cost & 3.396 & 0.068 & -0.250 & 0.803 & Not significant \\
Labor Availability & 2.992 & 0.087 & -0.053 & 0.958 & Not significant \\
Competitive Hostility & 0.014 & 0.906 & -0.168 & 0.870 & Not significant \\
Market Dynamism & 3.179 & 0.078 & 0.812 & 0.418 & Not significant \\
Low Cost & 6.400 & 0.013 & 1.402 & 0.174 & Not significant \\
Quality & 3.141 & 0.079 & 0.266 & 0.791 & Not significant \\
Flexibility & 1.978 & 0.163 & 0.446 & 0.656 & Not significant \\
Delivery & 0.041 & 0.840 & 0.766 & 0.445 & Not significant \\
\hline
\end{tabular}

\subsection{Variable and Measurement}

The questionnaire design required a number of measures.

Environment: Three dimensions of the environment include munificence, dynamism and complexity (Badri et al., 2000). The current study focused on the effect of munificence and dynamism, and thus does not include an environmental complexity scale. Three scales are included related to environmental munificence: eight questions were used to measure business cost, six questions were used to measure labor availability, and seven questions were used to measure competitive hostility. The environmental dynamism consists of four questions to measure degree of unpredictability change in environmental condition faced by the firm. All statements about the business environment were measured on five point Likert scales.

Manufacturing Strategy: The manufacturing strategy was operationalized using Badri et al. (2000) classification of manufacturing strategies namely low cost, quality, flexibility, and delivery. Four questions were used to measure cost strategy, six questions were used to measure quality strategy, and five questions for each flexibility and delivery strategy. All of the questions were measured on five point Likert scale Here the respondents are asked to indicate their importance to the statement of each manufacturing strategy. 


\section{RESULT AND DISCUSSION}

\subsection{Respondent Profiles}

The profiles of 106 selected companies are shown in Table 4. The 106 chosen companies operate in food, beverage, tobacco, textile, garment, plywood, rattan, chemical, metallic, plant and equipment, and also machinery industries. Majority (54.72\%) of responding firms had more than 3000 full time employees about $97.17 \%$ of them have assets in excess of 25 million Rupiah. Most of them have been in existence for more than 10 years. Majority of respondent (32.08\%) firms were in metal, machinery, and electronics industry. The smallest group came from food, beverage, and tobacco industry (6.60\%). In term of ownership, approximately $84 \%$ were Indonesian owned.

Table 4.

Sample Profile

\begin{tabular}{|c|c|c|c|}
\hline Dimension & Categories & $\begin{array}{l}\text { Total of res- } \\
\text { pondents }\end{array}$ & Percentage \\
\hline \multirow[t]{4}{*}{ Length of operation } & $5-10$ years & 17 & 16.04 \\
\hline & $>10-20$ years & 38 & 35.85 \\
\hline & $>20-30$ years & 32 & 30.19 \\
\hline & More than 30 years & 19 & 17.92 \\
\hline \multirow[t]{6}{*}{ Operation area } & Food, Beverage, tobacco & 7 & 6.60 \\
\hline & Textile, garment, leather & 14 & 13.21 \\
\hline & Rattan, bamboo, furniture and handy craft & 13 & 12.26 \\
\hline & Chemical, oil, coal, and plastic & 24 & 22.64 \\
\hline & Non metallic and mineral & 14 & 13.21 \\
\hline & Metal, machinery, and electronic & 34 & 32.08 \\
\hline \multirow[t]{3}{*}{ Owners } & Local & 84 & 79.24 \\
\hline & Foreign & 17 & 16.04 \\
\hline & Joint venture & 5 & 4.72 \\
\hline \multirow[t]{6}{*}{ Cooperation } & No cooperation & 43 & 40.57 \\
\hline & Japan & 29 & 27.36 \\
\hline & Hongkong, Taiwan, Korea & 12 & 11.32 \\
\hline & ASEAN & 3 & 2.83 \\
\hline & USA, UK, Australia & 11 & 10.38 \\
\hline & Others & 8 & 7.54 \\
\hline \multirow[t]{4}{*}{ Number of employee } & 100 - 999 employees & 21 & 19.81 \\
\hline & 1000 - 1999 employees & 10 & 9.43 \\
\hline & 2000 - 2999 employees & 17 & 16.04 \\
\hline & 3000 employees & 58 & 54.72 \\
\hline \multirow{6}{*}{$\begin{array}{l}\text { Performance in the } \\
\text { last three years }\end{array}$} & & & \\
\hline & Decrease > $15 \%$ & 14 & 13.21 \\
\hline & Decrease $<15 \%$ & 16 & 15.09 \\
\hline & Not change & 18 & 16.98 \\
\hline & Increase $<15 \%$ & 47 & 44.34 \\
\hline & Increase $>15 \%$ & 11 & 10.38 \\
\hline
\end{tabular}




\begin{tabular}{llrr} 
Asset & Less than 25 billion Rupiah & 3 & 2.83 \\
& $25-100$ billion Rupiah. & 32 & 30.19 \\
& $>100-500$ billion Rupiah. & 41 & 38.68 \\
& $>500-1000$ billion Rupiah. & 14 & 13.21 \\
& More than 1 billion Rupiah. & 16 & 15.09 \\
\hline
\end{tabular}

\subsection{Scale Reliability and Construct Validity}

To test the construct validity, we used confirmatory factor analysis. The loading factor for each dimension of the variable is above 0.55 , the minimal standard of loading factor for a sample of 100 respondents (Hair et al., 1998). For business environment dimensions, business cost (the loading factor ranged from 0.572-0.823), labor availability (the loading factor ranged from $0.775-0.850$ ), competitive hostility (the loading factor ranged from 0.584 to 0.786 ), market dynamism (the loading factor ranged from 0.559 to 0.584 ). The loading factor for manufacturing strategy dimensions ranged from 0.550 to 0.868 . The loading factor for low cost $(0.770-0.868)$, quality $(0.550$ $0.801)$, flexibility (0.603 - 0.847), and delivery (0.765 - 0.862).

Cronbach's reliability coefficient alpha values for each scale ranged from 0.712 to 0.897 for the environment dimensions. More specifically: business cost (0.830), labor availability (0.897), competitive hostility (0.712), and market dynamism (0.801). The coefficients ranged from 0.825 to 0.896 for the manufacturing strategy dimensions, low cost $(0.849)$, quality $(0.825)$, flexibility $(0.858)$, delivery $(0.896)$.

Table 5.

Scale Reliability and Construct Validity

\begin{tabular}{clcc}
\hline Variable & \multicolumn{1}{c}{ Dimension } & $\begin{array}{c}\text { Loading } \\
\text { Factor }\end{array}$ & $\begin{array}{c}\text { Cronbach's } \\
\text { Alpha }\end{array}$ \\
\hline Business Environment & Business Cost & $0.572-0.823$ & 0.830 \\
& Labor Availability & $0.775-0.850$ & 0.897 \\
& Competitive Hostility & $0.584-0.786$ & 0.712 \\
& Market dynamism & $0.559-0.854$ & 0.801 \\
Manufacturing Strategy & Low Cost & $0.770-0.868$ & 0.849 \\
& Quality & $0.550-0.801$ & 0.825 \\
\cline { 2 - 4 } & Flexibility & $0.603-0.847$ & 0.858 \\
& Delivery & $0.765-0.862$ & 0.896 \\
\hline
\end{tabular}

\subsection{Descriptive Statistic for Business Environment and Manufacturing Strategy}

Table 5 show the mean value, standard deviations (S.D.) and the emphasized level of manufacturing firm in Indonesia on environmental variables. Based on the information shown, competitive hostility, market dynamism, and business cost are three highest dimensions of business environment. Indonesia manufacturing firms give high emphasized on some factors consist of: producing to the required standard of quality (4.0377), keen competition in local market (3.3679), rising material cost (3.3679), rate of innovation of new operation process (3.4906), rate of innovation of new product (3.4906), rate of change in taste and preference of customers (3.4714), rising in labor cost (3.3679), rising in transport cost (3.3396), low profit margin (3.3208), and declining demand in foreign market (3.2264). 
Table 6.

Descriptive Statistic for Business Environment

\begin{tabular}{|c|c|c|c|}
\hline Environmental Variable & $\begin{array}{l}\text { Mean- } \\
\text { Mean }\end{array}$ & S.D. & Rank \\
\hline \multicolumn{4}{|l|}{ Business Cost } \\
\hline Rising labor cost(BC1) & 3.3679 & 0.87642 & 7 \\
\hline Rising material cost (BC2) & 3.5755 & 0.86132 & 3 \\
\hline Rising transport cost (BC3) & 3.3396 & 0.71563 & 8 \\
\hline Rising telecommunication cost (BC4) & 3.1887 & 0.92698 & 12 \\
\hline Rising utility cost (BC5) & 3.0283 & 0.76167 & 15 \\
\hline Rising rental cost $(\mathrm{BC} 6)$ & 2.6604 & 0.95505 & 16 \\
\hline Rising health care cost (BC7) & 3.1415 & 0.82160 & 13 \\
\hline \multicolumn{4}{|l|}{ Labor Availability } \\
\hline Shortage of managerial and administrative staff (LA1) & 2.3396 & 0.90382 & 17 \\
\hline Shortage of technicians (LA2) & 2.0849 & 0.89568 & 20 \\
\hline Shortage of clerical and related workers (LA3) & 2.2547 & 0.96670 & 18 \\
\hline Shortage of skilled workers (LA4) & 1.9434 & 0.8818 & 21 \\
\hline Shortage of production workers (LA5) & 2.1698 & 0.99016 & 19 \\
\hline \multicolumn{4}{|l|}{ Competitive Hostility } \\
\hline Keen competition in local ma & 3.3679 & 0.87642 & 2 \\
\hline Low profit margins $(\mathrm{CH} 3)$ & 3.3208 & 0.91075 & 9 \\
\hline Declining demand in local market $(\mathrm{CH} 4)$ & 3.1038 & 1.20261 & 14 \\
\hline Declining demand in foreign market (CH5) & 3.2264 & 1.10654 & 10 \\
\hline Producing to the required quality standards $(\mathrm{CH} 6)$ & 4.0377 & 0.77980 & 1 \\
\hline \multicolumn{4}{|l|}{ Market Dynamism } \\
\hline $\begin{array}{l}\text { Rate at which products and services become outdated } \\
\text { (DM1) }\end{array}$ & 3.1981 & 0.89889 & 11 \\
\hline Rate of innovation of new products and services (DM2) & 3.4906 & 0.85351 & 5 \\
\hline Rate of innovation of new operation processes (DM3) & 3.4906 & 0.70704 & 4 \\
\hline Rate of change in taste and preferences of customers(DM4) & 3.4714 & 0.81891 & 6 \\
\hline
\end{tabular}

The level of emphasized on manufacturing strategy are shown in Table 6. those discuss the mean value, standard deviations (S.D.) and rank of level emphasized. 
Table 7.

Descriptive Statistic for Manufacturing Strategy

\begin{tabular}{|c|c|c|c|}
\hline Manufacturing Strategy & $\begin{array}{l}\text { Mean- } \\
\text { Mean }\end{array}$ & S.D. & Rank \\
\hline \multicolumn{4}{|l|}{ LOW COST STRATEGY } \\
\hline Reduce unit costs (C1) & 4.4057 & 0.77801 & $\begin{array}{l}1 \\
1\end{array}$ \\
\hline Reduce material costs (C2) & 4.2075 & 0.82482 & 5 \\
\hline Reduce overhead costs (C3) & 3.9906 & 0.83376 & 8 \\
\hline Reduce inventory level (C4) & 4.2075 & 0.82482 & 6 \\
\hline \multicolumn{4}{|l|}{ QUALITY STRATEGY } \\
\hline Reduce defective rates (Q1) & 4.3962 & 0.75188 & 2 \\
\hline Improve product performance and reliability(Q2) & 4.2264 & 0.73398 & 4 \\
\hline Improve supplier and vendor's quality (Q3) & 4.0000 & 0.67612 & 7 \\
\hline Implement quality control circles (Q4) & 4.2736 & 0.73722 & 3 \\
\hline Obtaining international quality certification(Q5) & 3.8962 & 1.05044 & 10 \\
\hline Obtaining local quality certification (Q6) & & 0.99075 & 13 \\
\hline \multicolumn{4}{|l|}{ FLEXIBILITY STRATEGY } \\
\hline Reduce manufacturing lead-time (F1) & 3.6792 & 0.87882 & 15 \\
\hline Reduce procurement lead-time (F2) & 3.5849 & 0.84929 & 18 \\
\hline Reduce new product develop cycle (F3) & 3.4434 & 0.95698 & 20 \\
\hline Reduce set up/changeover time (F4) & 3.7075 & 0.98529 & 14 \\
\hline Increasing product type and variation (F5) & 3.5566 & 0.89528 & 19 \\
\hline \multicolumn{4}{|l|}{ DELIVERY STRATEGY } \\
\hline Increase delivery reliability (D1) & 3.9057 & 0.76256 & 9 \\
\hline Increase delivery speed (D2) & 3.8585 & 0.82160 & 11 \\
\hline Improve pre-sales service and technical support (D3) & 3.7642 & 0.90028 & 12 \\
\hline Improve technical service to customers (D4) & 3.6509 & 1.07882 & 16 \\
\hline Improve after sales service (D5) & 3.5943 & 0.99310 & 17 \\
\hline
\end{tabular}

Based on Table 6, low cost strategy, quality strategy, and delivery strategy are three highest emphasized of manufacturing strategy. Indonesia manufacturing firms give high emphasized on some factors consist of: reduce unit costs (4.4057), reduce defective rates (4.3962), implement quality control circles (4.2736), improve product performance and reliability (4.2264), reduce material costs (4.2075), reduce inventory level (4.2075), improve supplier and vendor's quality (4.0000), reduce overhead costs (3.9906), increase delivery reliability (3.9057), obtaining international quality certification (3.8962)

\subsection{The Impact of Business Environment on Manufacturing Strategy Choice}

Table 5 presents the result of multivariate multiple regression analysis (MMRA), to test the impact of environmental factors of business cost, labor availability, competitive hostility, and market dynamism on the degree of emphasis on manufacturing strategy choice of low cost, quality, flexibility, and delivery. 
Table 8.

The Impact of Business Environment on Manufacturing Strategy Choice

\begin{tabular}{|c|c|c|c|c|c|c|}
\hline \multirow{2}{*}{$\begin{array}{l}\text { Dependent } \\
\text { Variable }\end{array}$} & \multirow{2}{*}{$\begin{array}{l}\text { Para- } \\
\text { meter }\end{array}$} & \multicolumn{2}{|c|}{$t$ test } & \multicolumn{2}{|c|}{ F test } & \multirow[t]{2}{*}{ R2 } \\
\hline & & $t$ & sign & $\mathbf{F}$ & Sign & \\
\hline \multirow[t]{5}{*}{ COST } & Intercept & 6.778 & 0.000 & 2.531 & 0.045 & 0.091 \\
\hline & Business Cost & 0.156 & 0.877 & & & \\
\hline & Labor Availability & 2.695 & 0.008 & & & \\
\hline & $\begin{array}{l}\text { Competitive Hostil- } \\
\text { ity }\end{array}$ & 0.843 & 0.401 & & & \\
\hline & Market Dynamism & 0.408 & 0.684 & & & \\
\hline \multirow[t]{5}{*}{ QUALITY } & Intercept & 7.099 & 0.000 & 3.916 & 0.005 & 0.134 \\
\hline & Business Cost & 2.232 & 0.028 & & & \\
\hline & Labor Availability & 0.033 & 0.974 & & & \\
\hline & $\begin{array}{l}\text { Competitive Hostil- } \\
\text { ity }\end{array}$ & 0.988 & 0.325 & & & \\
\hline & Market Dynamism & 2.070 & 0.041 & & & \\
\hline \multirow[t]{5}{*}{ FLEXIBILITY } & Intercept & 2.598 & 0.011 & 8.475 & 0.000 & 0.251 \\
\hline & Business Cost & 3.247 & 0.002 & & & \\
\hline & Labor Availability & 0.639 & 0.524 & & & \\
\hline & $\begin{array}{l}\text { Competitive Hostil- } \\
\text { ity }\end{array}$ & 2.984 & 0.004 & & & \\
\hline & Market Dynamism & 1.383 & 0.170 & & & \\
\hline \multirow[t]{5}{*}{ DELIVERY } & Intercept & 4.663 & 0.000 & 2.921 & 0.025 & 0.104 \\
\hline & Business Cost & 0.170 & 0.865 & & & \\
\hline & Labor Availability & 0.917 & 0.361 & & & \\
\hline & $\begin{array}{l}\text { Competitive Hostil- } \\
\text { ity }\end{array}$ & 0.282 & 0.778 & & & \\
\hline & Market Dynamism & 2.854 & 0.005 & & & \\
\hline
\end{tabular}

This study found that the four regression models with low cost strategy, quality strategy, flexibility strategy, and delivery strategy as the dependent variable have $F$ test value with level of significant $<0.05$, those are 0.045 for low cost strategy, 0.005 for quality strategy, 0.000 for flexibility strategy, and 0.025 for delivery strategy. This study also found that business environment dimensions can explain the variation in the dependent variables (low cost, quality, flexibility, and delivery) simultaneously. This conclusion based on $R^{2}$ value for low cost strategy $(9.1 \%)$, quality strategy (13.4\%), flexibility strategy $(25.1 \%)$, and delivery strategy $(10.4 \%)$.

Path diagram was used in this study for easier understanding the impact of business environmental dimensions on manufacturing strategy choice (Carey, 1998 in Amoako et al. 2003), as shown in Figure 2. From the path diagram approach we can conclude the following significant business environment dimensions on manufacturing strategy choice: business cost and quality (sign $t=0.028$ ), business cost and flexibility (sign $t=0.002$ ), labor availability and low cost (sign $t=0.008)$, competitive hostility and flexibility (sign $t=0.004)$, market dynamism and quality (sign $t=$ 0.041 ), and market dynamism and delivery strategy (sign $t=0.005$ ). 


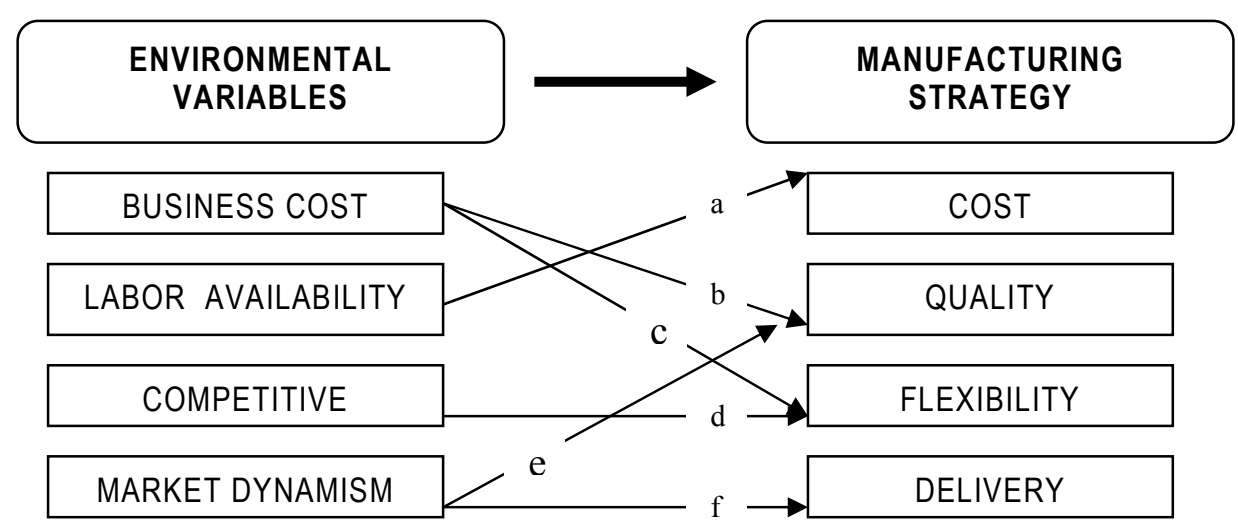

Figure 2.

Path Diagram Approach

t significant

$a=0.008 ; b=0.028 ; c=0.002 ; d=0.004 ; e=0.041 ; f=0.005$

\section{DISCUSSION AND CONCLUSION}

Based on the finding of the study, manufacturing firm in Indonesia were found to practice Badri et al (2000)'s manufacturing strategy (cost, quality, flexibility, delivery) to compete in Indonesian business environment. The significant relationship between business environment and manufacturing strategy implies the fact that business environment is considered as precursor variable that causally related to manufacturing strategy choice encompassed by competitive priorities.

The major finding of this research is that business environmental appears to have a substantial impact on manufacturing strategy choice. From business environment perspective, each of business environment dimensions has different impact on manufacturing strategy choice. Based on path diagram approach, business cost and market dynamism appears to have more impact on manufacturing strategy choice in the case of manufacturing firm in Indonesia. Business cost has significant impact and used as consideration to implement quality and flexibility strategy, while market dynamism has significant impact and used as consideration to implement quality and delivery strategy in manufacturing strategy choice. Labor availability and competitive hostility appears to have less impact on manufacturing strategy choice. Labor availability has significant impact on cost strategy, while competitive hostility has significant impact on flexibility strategy.

From manufacturing strategy perspective, manufacturing firm in Indonesia give more concern to quality and flexibility strategy that were impacted by business cost, competitive hostility, and market dynamism. This finding supported by the fact that manufacturing firms in Indonesia are faced the business condition, particularly the macro economy condition indicated by fluctuation of exchange rate. On the other hand, majority of manufacturing firms in Indonesia need to import raw material to support their production activities. For example is the case of automotive industry. In developing countries like Indonesia, there is practically no development or inventions in automotive technology and hence developing countries depend entirely on foreign car producers and foreign technology. Therefore, the only way to develop an automobile industry in developing countries is through technology transfer by buying technology needed from abroad (Tarmidi, 2001). This decision will have significant impact in increasing business cost or cost of production of manufacturing firms.

Manufacturing firm in Indonesia also faced more critical customer to get product or service with higher quality and shorter lead time. On the other hand they can not control the business competition resulted from more competitors in industry. To face this condition, companies should be more flexible and innovative in developing new product if they want to stay competitive and to achieve sustainability. To effectively compete in global market, 
manufacturing firm must quick and flexible in their response to customer need. Manufacturing strategic plan based on business environment and adoption of technology are important to compete globally. The role of technology adoption is automatically very important in this competitive market characterized by fast changing in technology development. Manufacturing firms need to shift their strategic priority from low cost production to quality strategy, flexibility strategy, delivery strategy, and implemented technology both hard and soft technology.

The theoretical and managerial implications of this study are clear. First, environmental consideration should be part of manufacturing strategy formulation to determine its competitive priority. Second, this study suggest, for Indonesian manufacturing firm to survive, need not only improve to its production capabilities based on the condition of business environment but also technology capability. The rapid rate of technological change and increasing industrialization become the major force in global business community, among these changes knowledge and intellectual capital management (technology management process) are needed. To success technology adoption nowadays are not coming from the architecture of technology as much as from the organization people, not from advance manufacturing technology but from people integrated manufacturing, a closed meshing of new hardware technology with human-embedded skills. Further, Indonesian manufacturing firms faced problems that related to human and thus need to focus on people issue such as conflict management and resistance to change during adoption and implementation. Training and innovative culture are needed to achieve adoption success. To successfully the adoption process, top management should create and maintain organizational culture or value. If top management is not committed to support incremental improvement practice, it will be difficult to expect employees across all levels to embrace an incremental improvement philosophy.

This study has a number of limitations. Data were collected based on perceived, self-judgment, multiplechoice questionnaire. It should be desirable to develop a longitudinal study, but it was entirely beyond the scope and the possibilities of the study. The questionnaires address to CEO (Chief Executive Officer), thus only CEOs responded as their perception business environment, manufacturing strategy, technological adoption, and the performance achieved. In this case the potential mono response bias emerges that is whether manufacturing manager response the same way or not. This research used multiple industries, the industry composition of the sample may account for variability in performance across firm, and therefore industry effect should be considered.

\section{REFERENCES}

Amoako, K., Gyampah, \& Boye, S.S. (2001), Operation Strategy In An Emerging Economy: The Case Of Ghanaian Manufacturing Industry, Journal of Operation Management, 19, pp. 59-79.

Amoako, K. (2003), The Relationship Among Selected Business Environment Factors And Manufacturing Strategy: Insights From An Emerging Economy, Omega International Journal of Management Science 31, pp.287301.

Autioe, A., \& Leimanen, T. (1995), Measurement And Evaluation Of Technology Transfer, International Journal of Technology Management, 10, pp. 643-664.

Badri, M.A., Davis, D. \&Davis, D. (2000), Operation Strategy, Environment Uncertainty, And Performance: A Path Analytic Model Of Industries In Developing Country, Omega International Journal of Management Science, 28, pp. 155-173.

Drucker, P.F. (1977), People and Performance: The Best of Peter Drucker on Management, London: Heineman Limited. 
Galbraith, C and Scendel, D. (1983), An Empirical Analysis of Strategy Types, Strategic Management Journal. Vol. 4, pp. 153-173.

Gerwin, D. (1993), Manufacturing Flexibility: A Strategic Perspective, Management Science, 39, pp. 395-410.

Glueck, W.F. (1980), Business Policy and Strategic Management, $3^{\text {rd }}$ ed New York: Mc Graw Hill.

Kourteli, L. (2000), Scanning the Business Environment, Benchmarking: An International Journal, 7 (5), pp. 406413.

Li, M., Simerly, R.L. (1998), The Moderating Effect Of Environmental Dynamism On The Ownership And Performance Relationship, Strategic Management Journal, 19, pp. 169-179

Leong, G.K., Synder, D.L. \& Ward, P.T. (1990), Research In The Process And Content Of Manufacturing Strategy. Omega International Journal of Management Science, 28. pp. 109-122.

Manu, F.A. \& Sriram, V. (1996), Innovation, Marketing Strategy, Environment and Performance, Journal of Business Research. 35, pp. 79-91.

Mc. Arthur, A.W., \& Nystrom, P.C. (1991), Environmental Dynamism, Complexity, and Munificence as Moderators of Strategy-Performance Relationships. Journal of Business Research, 23, pp. 349-361.

Miller, D. \& Friesen, P.H. (1983), Strategy-Making and Environment: The Third Link, Strategic Management Journal,, vol. 4, pp.221-235.

Mintzberg, H. (1979), The Structuring Of Organization, Prentice Hall, Englewood Cliff, NJ.

Nash. M. (1984), Managing Organizational Performance, San Fransisco: Josey Bass Publisher.

Porter, M. (1985), Competitive Advantage, New York: Free Press.

Stonebaker, P. \& Leong, G. (1994), Operation Strategy: Focusing Competitive Excellence, Boston, MA, Allyn and Bacon.

Swamidass, P.M. \& Newell, W.T. (1987), Manufacturing Strategy, Environmental Uncertainty And Performance: A Path Analytic Model, Omega International Journal of Management Science, 33 (4), pp. 509-524.

Tarmidi, L.T. (2001), Indonesian Industrial Policy For The Automobile Sector With Focus On Technology Transfer, International Institute for Asian Studies in Leiden, the Netherlands, 11-12 October, 2001.

Venkrataman, N and Prescott, J.E. (1990), Environment-Strategy Coalignment: an Empirical Test of Its Performance Implications, Strategic Management Journal, 11, pp1-23.

Ward, P.T., Bickford, D.J., Leong, G.K. (1995), Business Environment, Operation Strategy, And Performance: An Empirical Study Of Singapore Manufacturers, Journal of Operation Management 13 (2), pp. 99-155.

Warnock, I. (1996), Manufacturing and Business Excellence: Strategies, Techniques, and Technologies, Prentice Hall Europe.

Wheelwright, S.C. \& Hayes, R.H. (1985), Competing Through Manufacturing, Harvard Business Review, JanuaryFebruary, pp. 99-109. 